Review Article

\title{
Shodhana Yogya - Ayogya (Indications and Contraindications for Shodhana)
}

\author{
Madhushree HS', Ganesh Puttur ${ }^{2}$ \\ ${ }^{1}$ Professor, ${ }^{2}$ Vice Principal, Professor \& Head, Department of Post Graduate Studies in Panchakarma, Sri Sri College of Ayurvedic \\ Science \& Research, Bangalore, Karnataka, India.
}

DOI: https://doi.org/10.24321/2394.6547.201908

\section{I $\quad \mathbf{N} \quad \mathbf{F} \quad \mathbf{O}$}

\section{Corresponding Author:}

Madhushree HS, Department of Post Graduate Studies in Panchakarma, Sri Sri College of Ayurvedic Science \& Research, Bangalore, Karnataka, India.

E-mail Id:

drmadhushreehs@rediffmail.com

Orcid Id:

https://orcid.org/0000-0002-7625-6104

How to cite this article:

Madhushree HS, Puttur G. Shodhana Yogya Ayogya (Indications and Contraindications for Shodhana). J Adv Res Ayur Yoga Unani Sidd Homeo 2019; 6(3\&4): 10-13.

Date of Submission: 2019-10-21

Date of Acceptance: 2020-12-22

\section{$\begin{array}{llllllll}\mathbf{A} & \mathbf{B} & \mathbf{S} & \mathbf{T} & \mathbf{R} & \mathbf{A} & \mathbf{C} & \mathbf{T}\end{array}$}

\begin{abstract}
The word Shodhana is having a lot of weightage with respect to the treatments in Ayurveda. This treatment is very effective, powerful for the maintenance of health in a Swasta individual and also for treating Atura. It is very much essential to know the proper disease conditions and suitable individual for Shodhana treatment. The disease of a person might be indicated, but the person may not be suitable. For a psoriasis patient, disease psoriasis is definitely suitable for Shodhana procedure by considering the disease, but same patient with the fierceful nature or patient is considering himself as having knowledge of treatment and disobedience with respect the instructions of the physician etc. makes that individual as unfit for the Shodhana procedure. This article throws light on taking a initial decision on the indications and contraindications for the Shodhana procedure.
\end{abstract}

Keywords: Shodhana, Bahu Dosha, Apatarpana, Vega Dharana

\section{Introduction}

Ayurveda treatments have different Modalities. Hence, for a same condition and same patient, a physician can select different modalities of treatments and results are seen. It depends upon the strength, command and rationality in selecting the treatments makes the difference. Shamana and Shodhana are the two main varieties of treatments in Ayueveda. Shamana is the one where in palliative treatment is carried out. In Shodhana treatment morbid Doshas are eliminated from the body through a systematic sequence of steps. ${ }^{1}$

\section{General Concept of Shodhana}

Shodhana Procedure is a very effective treatment modality; where in the proper execution of the treatment will see that the relapse of the disease is not seen. ${ }^{2}$ Sushrutacharya narrates a guideline as, Ksheena Dosas should be increased/ nourished (Brihmayitavyaha). Kupita doshas should undergo Prashamana Chikitsa. Nirharana should be done for Vriddha doshas and those in Samaavastha should be maintained (Paripalana). ${ }^{3}$

Kshenah is nothing but decrease, and Ksheena Dosha Laxanas can be known by their features. Slightly aggravated Doshas are termed as Kupita. Vriddha is a quite advanced stage having moved from their place which should be eliminated by Shodhana Procedures. Further Dallhanacharya goes one step ahead by telling that Vilayanroopa Vriddhi has to be managed by Shodhana Treatment. ${ }^{4}$

\section{Indications of Shodhana}

Panchakarma (five purificatory therapies) described, bestow happiness to both the patients and healthy persons by 
promoting their strength and longevity, and also by curing their diseases. ${ }^{5}$

The physician desirous of administering Vamana or Virechana to a resourceful person like a king or somebody of that status, should collect all requirements well in advance of the actual treatment. ${ }^{6}$ Here Charakacharya takes the example of king or somebody of that status. Here he highlights that the Shodhana procedures are expensive and can be afforded by high status people only, who have the capacity to collect all the men and materials (to carry out treatment and treat probable complications) required for the Shodhana treatment.

Further Charakacharya mentions that the needy, poor patients also should be treated with Shodhana Treatment. A poor man in the event of emergency requiring the administration of Shodhana therapy, should take the prescribed drugs available without caring for collecting all the rare medicaments in advance. So in the case of emergency, whatever the drugs are available with those the Shodhana therapy has to be initiated by the physician. ${ }^{7}$

Indications for Shodhana Procedures can be highlighted under the headings of Swastha and Atura Avasta.

\section{Swastha}

Rutu Shodhana (Seasonal Detoxification): Due to the extremes of weather conditions in different seasons, people are likely to suffer from morbid accumulation of the doshas and the resultant illness. These influences are best treated by the detoxification procedures. Due to the seasonal effect on the human body in Vasanta Rutu (15 $5^{\text {th }}$ of February - $15^{\text {th }}$ of April), Sharat Rutu (15 $5^{\text {th }}$ of October $-15^{\text {th }}$ of December) and Pravrit Rutu (15 $5^{\text {th }}$ of June $-15^{\text {th }}$ of August) physiological accumulation of Kapha, Pitta and Vata doshas happens respectively and these are to be eliminated from the body through Vamana, Virechana and Vasti which makes the person healthy and help to increase the immunity. This also helps in prevention of forthcoming diseases.

Shodhana Prior to Rasayana: By the administration of the Shodhana Procedures, an individual should be cleansed, whenever the patient is comfortable, happy, regains his strength, then the Rasayna Chikitsa has to be administered ${ }^{8}$. Sushrutacharya narrates a simile to highlight the importance of Shodhana before the Rasayana Treatment. If coloring is done for a dirty cloth, proper coloring of the cloth will not happen and the purpose is not served, similarly for an uncleansed body if Rasayana Chikitsa is done, then the effect of Rasayana will not happen in the desired way ${ }^{9}$.

\section{Atura}

As a part of Langhana Chikitsa: Individual should be subjected to Langhana by means of Shodhana Chikitsa in those who are having well built body and strength, abundant
Kapha, Pitta and Rakta, Mala and association of aggrevated Vayu. ${ }^{10}$ In Ashtanga Hridaya we will find the additional information with respect to the disease conditions viz. those suffering from Amadosa, fever, vomiting, diarrhoea, heart disease, constipation, feeling of heaviness, excess of belching, nausea etc, wherein the administration of Shodana is adviced. ${ }^{11}$

As a Part of Apatarpana Chikitsa: In case of Bahu (abaundant) Dosas, only letting out of Dosas is prescribed. There is no remedy for over flowing of a small pool except by breaking down the field barriers. ${ }^{12}$ The therapy of letting out Dosas works in the same way. Set of Bahu Dosa Laxanas are enlisted which determines the Bahudosha Avastha and is indicated for Shodhana procedure. The Laxanas are indigestion, anorexia, obesity, paleness, heaviness, exhaustion and appearance of boils, urticarial rashes, itching, uneasiness, lassitude, fatigue, debility, foul smell, depression, regurgitation of Kapha and Pitta, sleeplessness or over sleep, drowsiness, impotency, intellectual impairment, inauspicious dreams, loss of strength and complexion even after saturation with body promoting nutrients. $^{13}$

As a Part of Treatment in Vegadharanajanya Rogas: In Ayurveda 13 Vegas (natural urges) are mentioned and suppression of these urges is contraindicated. If done they will lead to different disease conditions. ${ }^{14}$ Shodhana procedure is indicated in such diseases also. For example in case of Mutra Dharana Janya Rogas - Trividha Vasti Karma, in Pureeshadharana Janya Rogas - Vasti, in Kshavathu Vega Dharana Janya Rogas - Nasya etc. are adviced.

\section{Contra Indications of Shodhana}

Even though required in the view of the state of disease elimination therapies, other forms of depletion therapies, and nourishing therapies should not be administered to such of the patients as have not been absolved as the allegations against them, those who are incapable of meeting their expenditure, those who pose themselves as physicians, those who have violent behavior and jealous, who do not have faith in Dharma, whose Bala, Mamsa and Shonita have undergone excessive diminution, those who are suffering from incurable diseases and those who are having symptoms of imminent death. If the physician takes such patients, under his treatment, then he is defamed. ${ }^{15}$

The wise physicians should not give Panchakarma therapies to the following types of patients.

1. Who is Chanda (fierceful), Sahasika (rashful), Bhiru (cowardly), Kritaghna (ungrateful) and Vyagra (angry person).

2. Who hates good person, king and physicians and who is hated by them.

3. Who is afflicted with grief. 
4. Who does not believe in god.

5. Who is in the terminal stage of disease and destined to die.

6. Who is unable to arrange the essential items for treatment.

7. Who is enemy to the physician

8. Who is an imposter and considers himself to be a physician.

9. Who is devoid of faith in the physician.

10. Who is having doubtful nature.

11. Who does not carry out the instruction of the physician. ${ }^{16}$

The physician who administers the Shodhana therapy to the above mentioned patients invites many difficulties upon himself. These people will definitely not follow the shodhana procedures properly resulting in complications, bringing bad name to the physician and Ayurveda. Hence, the physician should be very careful while choosing the patient for shodhana procedure.

In Vishushka person due to Vata, Atapa, Adhva and Yana, those who are actively engaged in strenuous physical work, the physician should not administer Shodhana procedure to such persons. ${ }^{17}$

In persons having Ruksha Ahara, habitual exercise, stimulated digestive fire - the impurities gets diminished by physical exercise, exposure to wind, sun and fire. They also tolerate untoward effects of Virudha Ahara (incompatible food), Adyashana (intake of meal when the previous meal is not digested) or Ajeerna (indigestion). These persons should be protected from Vayu with Snehana and Shodhana should not be done except in illness. ${ }^{18}$

\section{Conclusion}

Shodhana procedures are indicated both in Swasta and Atura. As mentioned in the classics when the accumulated Doshas are expelled according to the season in Swasta, further progression of the pathology is controlled, thereby preventing the onset of diseases. Shodhana is the treatment of choice in diseases which are chronic in nature and where there is excessive aggravation of Doshas. The contra indication of Shodhana depends on various factors like strength, age, stage of a disease etc. If the Shodhana procedures are performed in contra indicated person or patient, it can result in serious complications. So, the physician should be very careful in choosing a person for Shodhana.

\section{Conflict of Interest: None}

\section{References}

1. Vagbhata, Astangha Hrudhayam, Dvividhopakramaneeyam Adhyayam, Sutrasthana, chapter 14, verse $5^{\text {th }}$, edited by Pt. Hari Sadhashiva Shastri Paradakara
Bishagacharya, reprint ed. Varanasi Chaukhamba Surbharati Prakashan. 2011; 223.

2. Agnivesa, Caraka, Drdhabala, Caraka Samhita, Chikitsaprabritheyamadyayam, Sutrasthana, chapter 16 , verse 20, edited by Dr. Brahmananda Tripathi, reprint ed. Varanasi, Chaukhamba Surbharati Prakashan, 2014; 323.

3. Susruta, Sri Dalhanacharya, Susruta, Vaman avirechana sadhyo upadrava Chikitsa, Chikitsa Sthana, chapter 33, verse 3, edited by Vaidya Yadavji Trikamji Acharya and Narayan Ramacharya Kavyatirtha. Reprint ed. Varanasi, Chowkhamba Krishnadas Academy. 2004; 515.

4. Dalhanacharya, Susruta Samitha, Vaman avirechana sadhyo padrava Chikitsa, Chikitsa Sthana, chapter 33, verse 3, edited by Vaidya Yadavji Trikamji Acharya and Narayan Ramacharya Kavyatirtha. Reprint ed. Varanasi, Chowkhamba Krishnadas Academy. 2004; 515.

5. Agnivesa, Caraka, Drdhabala, Caraka Samhita, Kalpana Siddhi, Siddhi Sthana, chapter 1, verse 53, edited by Prof. R.H. Singh, $1^{\text {st }}$ ed. Varanasi, Chaukhamba Surbharati Prakashan. 2011; 1628.

6. Agnivesa, Caraka, Drdhabala, Caraka Samhita, Upakalpaneeyamadhyayam, Sutrasthana, chapter 15, verse 3, edited by Dr. Brahmananda Tripathi, reprint ed. Varanasi, Chaukhamba Surbharti Prakashan. 2014; 320.

7. Agnivesa, Caraka, Drdhabala, Caraka Samhita, Upakalpaneeyamadhyayam, Sutrasthana, chapter 15, verse 19-21, edited by Dr. Brahmananda Tripathi, reprint ed. Varanasi, Chaukhamba Surbharti Prakashan. 2014; 320.

8. Agnivesa, Caraka, Drdhabala, Caraka Samhita, Rasayanadhyayam, Chikitsa Sthana, chapter 1,verse 24, edited by Prof. R. H. Singh, $1^{\text {st }}$. ed. Varanasi, Chaukhamba Surbharati Prakashan. 2011; 799.

9. Susruta, Sri Dalhanacharya, Susruta Samitha, Sarvopagatashamaneeyam Rasayanam, Chikitsa Sthana, chapter 27, verse 4, edited by Vaidya Yadavji Trikamji Acharya and Narayan Ramacharya Kavyatirtha. Reprint ed. Varanasi, Chowkhamba Krishnadas Academy. 2004; 499.

10. Agnivesa, Caraka, Drdhabala, Caraka samhita, Langanabrahmaneeyam Adhyayam, Sutrasthana, chapter 22, verse 19, edited by Dr. Brahmananda tripathi, reprint ed. Varanasi, Chaukhamba Surbharati Prakashan. 2014; 415.

11. Vagbhata, Astangha Hrudhayam, Dvividhopakramaneeyam Adhyayam, Sutrasthana, chapter 14 , verse 12, edited by Pt. Hari sdhashiva Shastri Paradakara bishagacharya, reprint ed. Varanasi Chaukhamba Surbharati Prakashan. 2011; 224.

12. Agnivesa, Caraka, Drdhabala, Caraka Samhita, Janapadhvodhwamsaneeyam Adhyayam, Vimanasthana, chapter 3 , verse 44 , edited by 
Dr. Brahmananda Tripathi, reprint ed. Varanasi, Chaukhamba Surbharati Prakashan. 2014; 688.

13. Agnivesa, Caraka, Drdhabala, Caraka Samhita, Chikitsaprabritheeyam Adhyayam, Sutrasthana, chapter 16, verse 13-14, edited by Dr. Brahmananda Tripathi, reprint ed. Varanasi, Chaukhamba Surbharati Prakashan. 2014; 323.

14. Agnivesa, Caraka, Drdhabala, Caraka Samhita, Naveganatharaneeyamadhyayam, Sutrasthana, chapter 7, Verse 5-6, edited by Dr. Brahmananda Tripathi, reprint ed. Varanasi, Chaukhamba Surbharti Prakash an, 2014; 165.

15. Agnivesa, Caraka, Drdhabala, Caraka samhita, Janapadhvodhwamsaneeyam Adhyayam, Vimanasthana, chapter 3 , verse 45 , edited by Dr. Brahmananda Tripathi, reprint ed. Varanasi, Chaukhamba Surbharati Prakashan. 2014; 688.

16. Agnivesa, Caraka, Drdhabala, Caraka samhita, panchakarmaneeyam siddhi, siddhi sthana, chapter 2, verse 4-7, edited by Prof. R. H. Singh, $1^{\text {st }}$ ed. Varanasi, Chaukhamba Surbharati Prakashan. 2011; 1631.

17. Bhela, Dr. K.H. Krishnamurty, Bhela samhita, Rituvibhageeyam, Sutrasthana, chapter 25, verse 7, edited by prof. Priya Vrat Sharma, reprint ed. Varanasi Chaukhamba Visvabharati. 2008; 105.

18. Agnivesa, Caraka, Drdhabala, Caraka samhita, Dantidravanti kalpam, Kalpasthana, chapter 12, verse 78-79, edited by Prof. R. H. Singh, $1^{\text {st }}$ ed. Varanasi, Chaukhamba Surbharati Prakashan. 2011; 1608. 